\title{
DYNAMICS OF GEODIVERSITY AND ECO-DIVERSITY IN TERRITORIAL SYSTEMS
}

\author{
Alexandru-lonuț PETRIŞOR, Cătălin Niculae SÂRBU \\ "Ion Mincu" University of Architecture and Urbanism, Bucharest, Romania
}

\begin{abstract}
Two concepts, the "territorial system" and the "ecosystem", describe similar realities from different standpoints. For both systems, one of the key features is diversity, called geodiversity in the first case, and eco- or biodiversity in the second. The paper analyzes their definitions and proposes a clarification: overlapping with geodiversity, eco-diversity includes biodiversity. In this interpretation, urbanization processes determine the loss of biodiversity, but increased geodiversity, reflected by the consumption of resources appreciated as primary eco-energies.
\end{abstract}

Key Words: geodiversity, eco-diversity, biodiversity, territorial system, ecosystem, eco-energy

\section{Territorial and ecological systems}

Territorial systems are "functional assemblies [...] constituted of elements and relationships, aiming to achieve common goals" (lanoş, 2000). Other authors focus their definition only on the structural elements (Wilson, 2000). The elements constitute natural and anthropic subsystems, substantially different (Fig. 1 and Fig. 2).

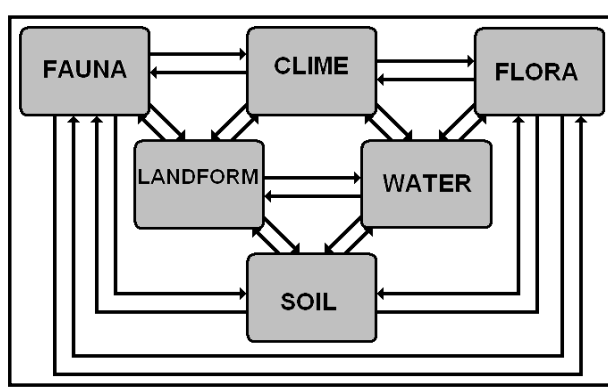

Fig. 1. - The natural territorial system (lanoş ,2000, simplified)

The base unit in ecology is the ecosystem defined by Arthur Tansley as "system... including not only the organism-complex, but also the whole complex of physical factors forming what we call the environment" (Tansley, 1935). Therefore, the ecosystem is formed by lifeless / abiotic components (the biotope) and living / biotic components (the biocoenose or community), as well as their relationships (Petrişor, 2008). Its model is replicated at the upper hierarchical levels; in complexes of ecosystems, the biotic components is a complex de biocoenoses or biome, and the abiotic one, a hydro-geomorphologic unit (river basin, delta, estuary, sea, ocean etc.) - Vădineanu, 1998. In the ecosphere, the biotic component is the biosphere. The abiotic one (troposphere) includes terrestrial geospheres: atmosphere, hydrosphere, lithosphere. The ecosphere also includes the antroposphere and its component, the technosphere (Vădineanu, 1998).

\section{Eco-diversity and geodiversity}

One of the defining characteristics of territorial and ecological systems is diversity (also called heterogeneity or variability). In statistics, diversity is perceived quantitatively as scatter around a central trend (Dragomirescu, 1998) and qualitatively as a different number of elements with 


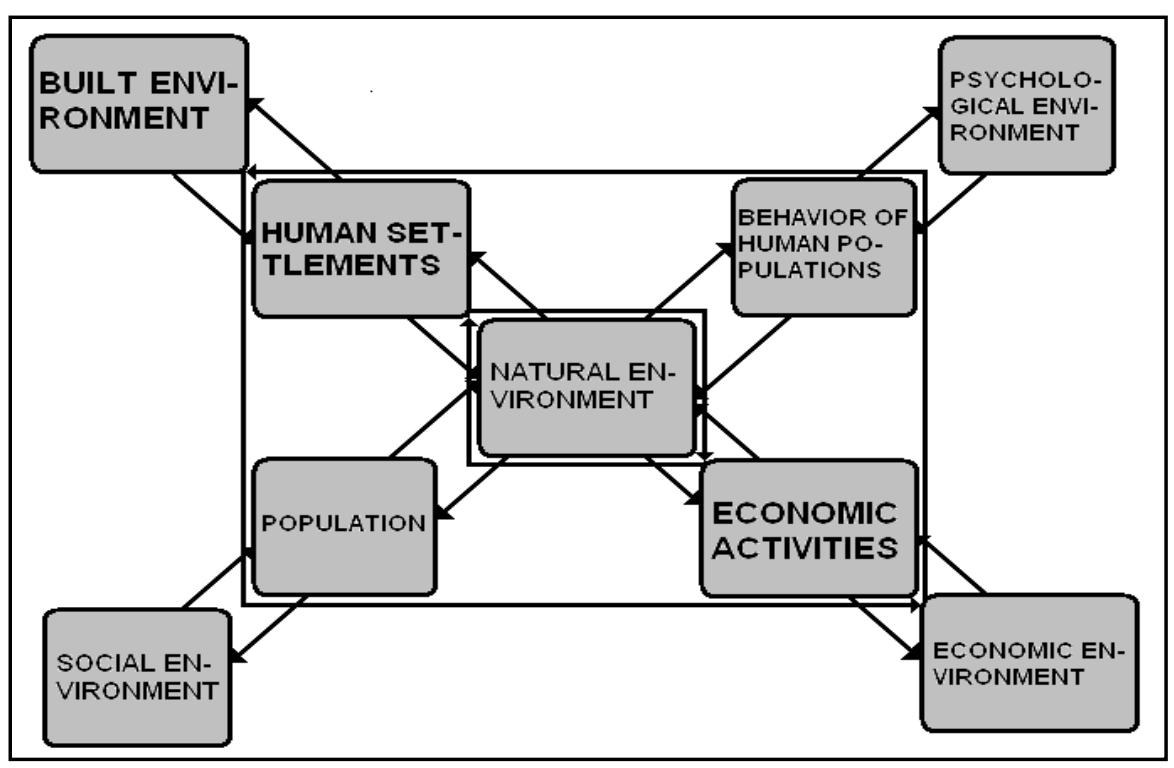

Fig. 2 - Strongly anthropized territorial system

(lanoş, 2000, simplified)

different frequencies - evenness of the distribution (Magurran, 1988; Dragomirescu, 1998). In ecology, it refers to the diversification of structure, relationships between the elements, and functions (Vădineanu, 1998; Petrişor, 2008). The diversity is named in geography, geodiversity and in ecology, bio- and eco-diversity. The concept of geodiversity is used by two disciplines. In geography it represents the heterogeneity of "geological (rocks, minerals, fossils), geomorphological (landforms, processes) and soil features; it includes their assemblages, relationships, properties, interpretations, and systems" (Gray, 2004). In geology it is defined as expression of the "geology of a region, including rocks, minerals, fossils, or geological structures open by natural or anthropic means" (Popa, 2007).

\begin{tabular}{|l|l|l|}
\hline Diversity & Ecology & Geography \\
\hline System & Ecodiversity Biodiversity & Geodiversity \\
& Bcosystem & (geology) \\
(geography)
\end{tabular}

Fig. 3 - Relationship between biodiversity, eco-diversity and geodiversity, correlated to the hierarchy of ecological and geographical systems 
Some authors believe that geodiversity and biodiversity overlap (Musila et al., 2005; Santucci, 2005), others believe that geodiversity includes biodiversity (Hakala, 2005), or the opposite (Vădineanu, 1998). The confusion originates mostly in semantics. The concept of "biodiversity" is etymologically built around the Greek ßíos (bios) - life: "variability among living organisms from all sources including, inter alia, terrestrial, marine and other aquatic ecosystems and the ecological complexes of which they are part; this includes diversity within species, between species and of ecosystems" (1992 Rio de Janeiro Convention on Biological Diversity). Nevertheless, the definition can be extended by adding abiotic components, provided the inclusion of the diversity of ecosystems "including not only the organism-complex, but also the whole complex of physical factors" (Tansley, 1935). The ecosystemic component was called eco-diversity, built etymologically around the ecosystem, and including living and lifeless components. The newer concept (eco-diversity) was embedded in the previous one (biodiversity) as an extension, despite of the opposite semantic relationship. This paper is based on considering that eco-diversity includes biodiversity, since the hierarchy of ecological systems embeds supra-specific biological systems. If understood, correctly, eco-diversity represents the diversity of natural and anthropic systems and coincides with geodiversity, including biodiversity (Fig. 3). Moreover, there are serious reasons to consider that from the conceptual level of systems to the one of diversity, conceptual distinctions relate more to the research methods specific to ecology, respectively to geography.

\section{Dynamics of coupled complexes of socio-ecological systems}

Regardless of the theory accounting for their dynamics (succession or adaptive cycles), ecological systems as life-support systems (Vădineanu, 1998, 2004), generate through the matter and energy flows a series of resources undertaken by the human socioeconomic systems as environmental goods and services (Negrei, 1999). The following paragraphs discuss the mechanism through which socioeconomic systems couple to the natural ones in order to absorb the resources required for their development (Vădineanu, 1998; Sârbu, 1999).

However, understanding the dynamics of socioeconomic systems requires a brief presentation of their function. In addition to the functions of natural systems (energy and matter flows and self-regulation), socioeconomic systems have new functions, as a consequence of the socioeconomic and cultural components, and even the common functions take place differently (Petrişor, 2008).

Biogeochemical circuits are modified and often become linear due to the pollution and overexploitation (Vădineanu, 1998), determining, among others, the loss of biodiversity due to the shortage of food chains, disappearance of species, habitats, and systems (Petrişor, 2008), but also due to a drastic diminishment of "environmental services" (e.g., due to the fact that the soil is covered by asphalt in the urban ecosystems and becomes impermeable, the global circuit of water is changed; the hydrological balance is in deficit and needs to be compensated by the creation of ponds - Petrişor, 2008). It is obvious that this topic is approached anthropocentrically, since the processes based on natural phenomena are considered to be oriented toward the satisfaction of human needs.

Matter and energy sources used by the socioeconomic system are not the sun or chemical energy as in natural systems, but socioeconomic systems are parasites of the natural ones and strictly dependant upon their highly concentrated energy and matter stocks (Vădineanu, 1998). Self-regulation is affected since the dominance of the human species results into reduced biodiversity and increased dependency of socioeconomic systems on the human species, subtracting it from natural laws to favor the human desires (Petrişor, 2008). It is evident that the 
"subtraction" is apparent, since the access to the stock of natural resources is an access "mediated" by the natural and semi-natural ecological systems to the radiant solar energy and the biochemical processes of the latter, subjugating, finally and fatally, the socio-economic system in general and human settlements in particular to the same implacable law of the limiting factors and to the same biogeochemical processes governing the structure and functions of natural systems. The difference resides in the quantity, density, and quality (diversity and distribution) of resources in socioeconomic systems compared to the natural ones, including the systemic resources specific to the first (social, economic, and cultural relationships, generating at their turn institutional structures and resources).

The dynamics of socioeconomic systems consists of stages of spatial, structural, and economic growth followed by structural and functional improvements (Vădineanu, 1998). The determining factors are exogenous (cosmic, geological - same as in natural systems) and endogen (dynamics of the human population, material and nonmaterial needs correlated to the development of social and institutional organization, and development of better means and technologies to access and utilize renewable and nonrenewable resources and services offered by the natural capital) - Vădineanu, 1998.

The coupling is made in all functional aspects.

- Matter flows are taken directly from the natural system. Man intervenes as a top consumer in food chains. Resources are taken directly from natural systems or upon transformation in anthropized systems, such as the agro-ecosystems.

- Energy (and resources) are taken using the technologies developed by the human species (Sârbu, 2006) - Fig. 4. From the energetic standpoint, socioeconomic systems dissipate natural energy, introducing it as fertilizers, pesticides, soil works, caring for the green spaces, food, etc. in amounts exceeding the contribution of primary producers (Petrişor, 2008). The amount and density of anthropic energy resources (meaning the energy manipulated by the socioeconomic system to maintain and develop its own subsystems, resulting into the modification of the structures and functions of the territory) increase in an urbanized territory compared to the adjacent territories covered by natural systems. The amount of energy absorbed is increased by diversifying the channels for absorbing resources, underlying the structuring character of human activities over the geographic space (Sârbu, 2006).

- The modification of biogeochemical circuits and loss of biodiversity determines a lower stability of socioeconomic systems; their self-regulation becomes dependant on human actions.

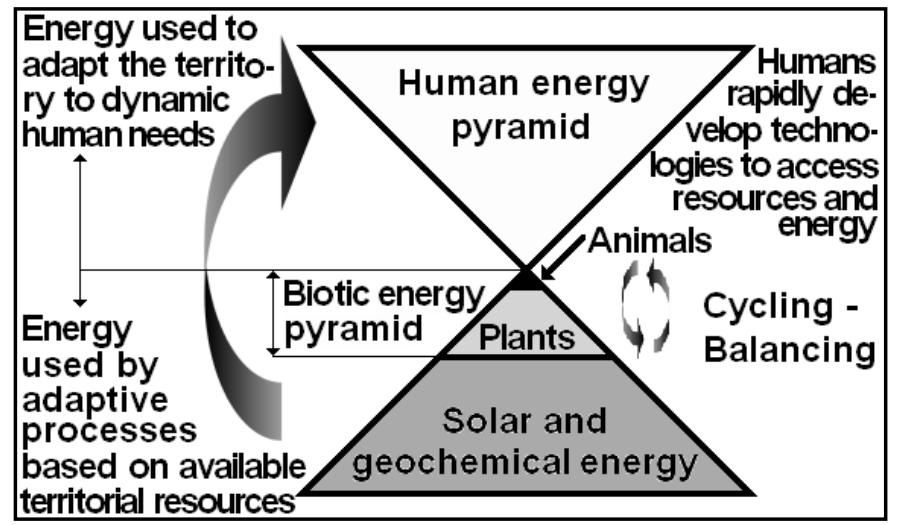

Fig. 4 - Coupling of socioeconomic systems to the natural ones in order to absorb energy (Sârbu, 2006) 
The dynamics is tightly and intrinsically related to two concepts, eco-energy and urbanization. Primary eco-energy is the initial energy of a territorial system before the conscious human intervention on its structure. During the urbanization, natural systems are first anthropized and then become anthropic; the concentration of population and economic activities determines a differentiated consumption of resources, appreciated as primary eco-energies (lanos, 2000). The assessment of eco-energies is based on the qualitative appreciation of the level of degradation in initial geosystems. The intensity of anthropization is inversely correlated with the distribution of primary eco-energies, and responsible for the increased complexity of geosystems (lanoş, 2000).

Socioeconomic systems tend to expand in space and replace the natural ones by anthropization and urbanization. The historical stages of their relationships are suggested in Fig. 5. The pressures on natural systems translate into impacts generally named environmental deterioration: overexploitation of natural resources, pollution, loss of eco-diversity and biodiversity, introduction of new species, fragmentation of habitats, genetic manipulations, important works on water courses (Petrişor, 2008), some of which were signaled in the 60's in Rachel Carson's Silent spring (Carson, 1962), and starting from the 70's economic, social, and political impacts during the oil crises.

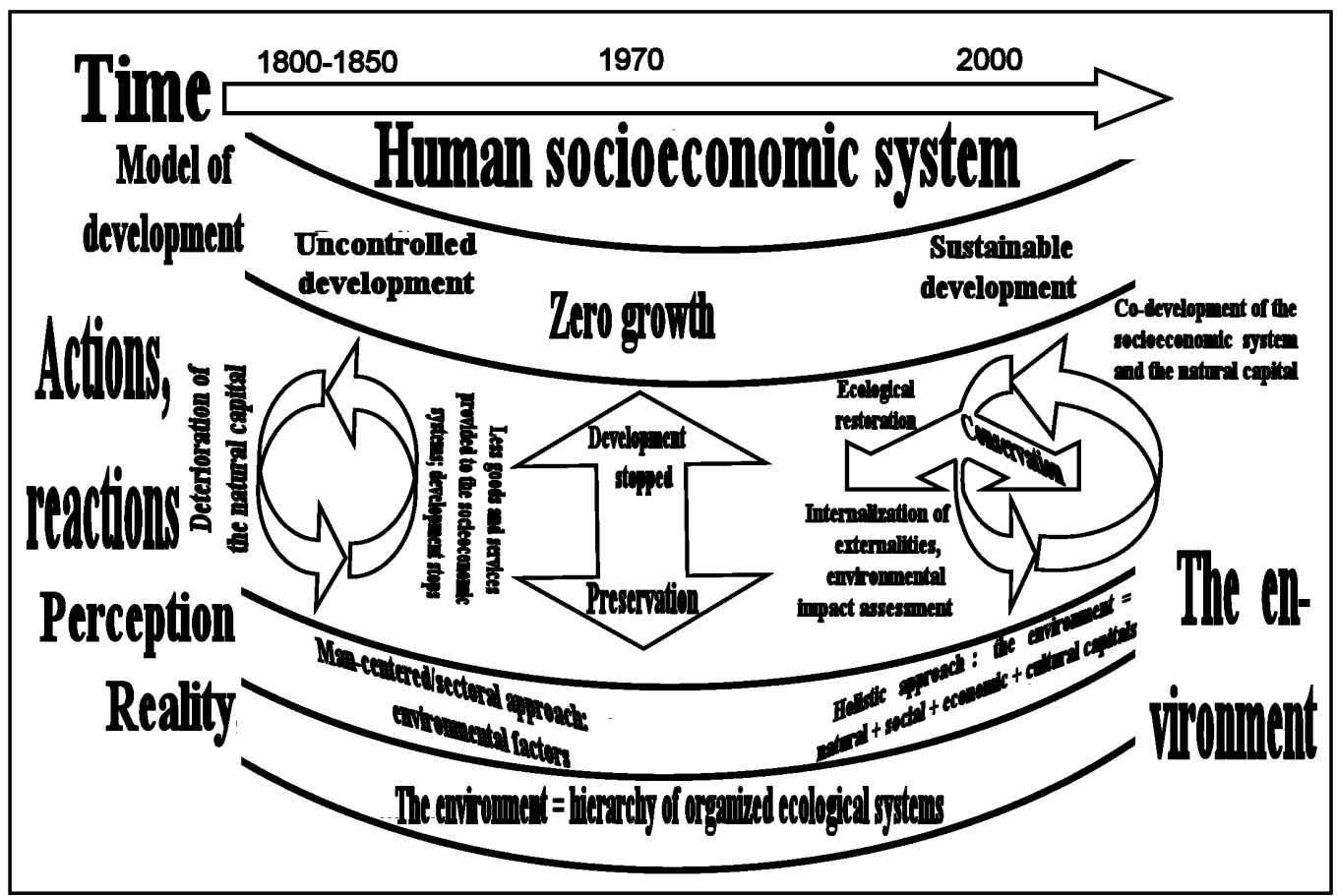

Fig. 5 - Environmental deterioration and sustainable development

The coordinates of the dynamics of socioeconomic systems are: (1) spatial expansion by substituting natural and semi-natural components of ecological networks with the spatial and technological components of socioeconomic systems and transforming them by simplification, fragmentation and restrained connectivity, (2) diversification and specialization of the inner structure, increased density of matter and energy flows, and of the volume of goods and 
services, (3) multiplication of channels for the absorption of renewable and nonrenewable resources and services, and increase of matter and energy flow for each channel, (4) growth and diversification of channels (punctual and diffuse) for the dispersion of secondary technological products, of the special ones (pesticides, detergents, CFCs), of the used ones, and of entropy, especially in the aquatic systems and troposphere, (5) increased material and energetic transfer rates, and linearization of biogeochemical circuits, (6) absorption, accumulation, concentration of nonrenewable mineral resources as wastes or built capital, parallel to the exhaustion of the natural capital stocks, and (7) regionalization and globalization of socio-ecological systems due to the increased interdependence among them (Vădineanu, 1998).

A first answer to these issues was the reaction of the Club of Rome, proposing the zero growth strategy, stopping both development and its impacts (Meadows et al., 1972). Since the solution was not feasible, researches continued and focused either on changing the consciousness and ethics (László, 2004), proposing technological solutions (Petrişor, 2008), diminishing the extended impact of megalopolis-type urban systems (Dansereau and Weadock, 1970), or economic, social or political issues (Petrişor, 2008). As a synthesis of these searches, the concept of sustainable development appears in 1987, defined as "development that meets the needs of the present without compromising the ability of future generations to meet their own needs" (Brundtland, 1987). The concept has a spatial dimension, and is based on three traditional pillars: economic, social and ecological (Petrişor, 2008). It is interesting to note that, based on the perspective of valorizing them in practice through specific policies, other "pillars" have been added (transport, cultural, political, institutional constructs). Consequently, integrating the practical aspects involved, sustainable development assumes the "utilization of natural resources within the limits of the carrying capacity, conservation of biodiversity, ecological restoration of deteriorated ecosystems and environmental protection actions included in sectoral strategies of development in order to internalize environmental costs and assess the environmental impact" (Petrişor, 2009) - Fig. 6.

Development in general and sustainable development in special represent processes where the relationships between natural, economic, social, and cultural systems is very complex and can be analyzed from an eco-energetic perspective (lanoş, 2000). A much simplified and mathematical model is an approach to sustainable development based on four types of capital: natural, created by man, human (knowledge and abilities) and social (Petrişor, 2008). Regardless of the conceptual model, three reports to the United Nations have clearly shown that the development did not become sustainable (Bass, 2007), and the practical implementations remains a challenge.

The principles of sustainable development are tightly connected to other important concept of European spatial development. For over a decade, a series of important EU documents related to a balanced territorial development have substantiated from a spatial perspective the phrasing and implementation of the "territorial cohesion" concept (European Commission, 1999; CEMAT, 2000). The territorial cohesion, defined as "balanced distribution of human activities within a territory" (DG Regional Policy, 2004) can be achieved one the one side by a polycentric structure. The European Spatial Planning Observation Network (ESPON) defines the polycentric urban system as "spatial organization of cities characterized by functional division of labor, economic and institutional integration, and political cooperation" (Nordic Centre for Spatial Development, 2003), and based on two types of aspects: territorial morphology (number of human settlements, hierarchy and distribution) and relationships (fluxes and cooperation) among them (Nordic Centre for Spatial Development, 2005). On the other side, the approach to a balanced development of the European continent through policies 
addressed to all types of territories start, from the 9th decade (European Commission, 1999; CEMAT, 2000; Council of Europe, 2001), from the affirmation of their morphological and functional diversity (geographic, ecological, economic, social and cultural).

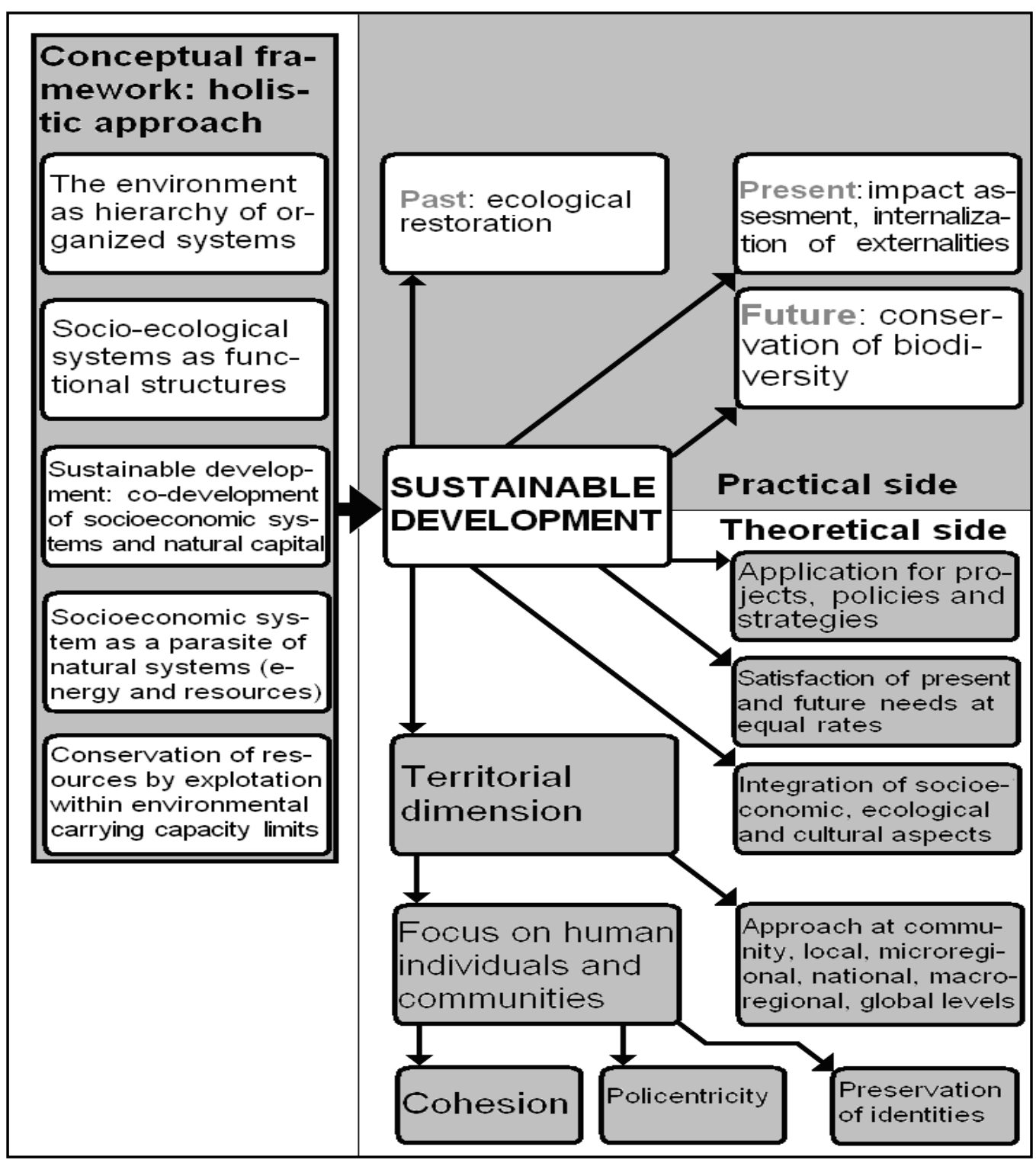

Fig. 6 - The concept of sustainable development 


\section{Dynamics of eco-diversity, biodiversity and geodiversity}

As it has been shown previously, the urbanization process transforms natural systems in anthropized and then anthropic systems; population and economic activities concentrate, determining a differentiated consumption of resources, measured based on the concept of primary eco-energy, inversely correlated with, the degree of anthropization (lanoş, 2000). Vădineanu (1998) shows that the processes adjacent to anthropization determine the simplification and fragmentation of natural habitats and loss of biodiversity. Concomitantly, urbanization results into the emergence of new structures, specific to the socio-economic systems (Sârbu, 1999), leading to an increased complexity of territorial systems (lanoş, 2000), translated into the growth of geodiversity. If natural resources are managed in an environmental-friendly manner (lanoş et al., 2009), consisting of a holistic managerial approach, primary diversity (biodiversity) is "amplified" statistically through the human contribution (Vădineanu, 2004), and geodiversity increases. According to these considerations, urbanization determines both increased geodiversity and loss of biodiversity; the economists sustain this hypothesis looking at the dynamics of the natural and created capital: the declining natural capital corresponds to the biodiversity, while the increasing created capital of socioeconomic systems reflects their geodiversity.

\section{Conclusions}

Diversity regarded in statistics qualitatively as different number of components and varied frequencies (Magurran, 1988; Dragomirescu, 1998), or in ecology as diverse structure, relationships, and functions (Vădineanu, 1998; Petrişor, 2008), allows for a coherent and functional analysis of the relationship between geodiversity and biodiversity. The anthropization of natural systems removes structural elements, determining functional damages and the loss of biodiversity, while the anthropic subsystems diversify through new structural elements and increased functional complexity during the acceleration of the urbanization process, resulting into the increase of geodiversity.

\section{Bibliography}

BASS S. (2007), A New Era in Sustainable Development. An IIED Briefing, International Institute for Environment and Development, London.

BRUNDTLAND G. H. (1987), Our Common Future, WCED, Oxford University Press, Oxford.

CARSON R. (1962), Silent Spring, Houghton Mifflin, Boston.

COUNCIL OF EUROPE (2000), European regional/spatial planning charter Torremolinos Charter, adopted on 20 May 1983 at Torremolinos (Spain), Council of Europe, Strasbourg, $18 \mathrm{p}$.

DANSEREAU P., WEADOCK V. A. (1970), Challenge for Survival: Land, Air, and Water for Man in Megalopolis, Columbia University Press, New York.

DG REGIONAL POLICY (2004), Third Interim Territorial Cohesion Report (Preliminary results of ESPON and EU Commission studies), Office for Official Publications of the European Communities, Luxemburg, p. 3.

DRAGOMIRESCU L. (1998), Biostatistics for Dummies [in Romanian], Editura Constelații, Bucharest, p. 37.

EUROPEAN COMMISSION (1999), Spatial Development Perspective Towards Balanced and Sustainable Development of the Territory of the European Union, Office for Official Publications of the European Communities, Luxembourg, $87 \mathrm{p}$. 
EUROPEAN CONFERENCE OF MINISTERS RESPONSIBLE FOR REGIONAL PLANNING - CEMAT (2000), Guiding Principles for Sustainable Spatial Development of the European Continent adopted at the 12th Session of the European Conference of Ministers responsible for Regional Planning on 7-8 September 2000 in Hanover, Council of Europe, Strasbourg, $25 \mathrm{p}$.

GRAY M. (2004), Geodiversity - valuing and conserving abiotic nature, John Wiley \& Sons, Chichester, $478 \mathrm{p}$.

HAKALA A. (2005), Paleoenvironmental and paleoclimatic studies on the sediments of Lake Vähä-Pitkusta and observations of meromixis, Publications of the Department of Geology D3, University of Helsinki, Helsinki, Finland.

Press, Bucharest.

IANOŞ I. (2000), Territorial systems. A geographic approach [in Romanian], Technical

IANOŞ I., PEPTENATU D., ZAMFIR D. (2009), Respect for environment and sustainable development, Carpathian Journal of Earth and Environmental Sciences 4(1), p. 81 93.

LÁSZLÓ E. (2004), Science and the Akashic Field: An Integral Theory of Everything, Inner Traditions, Rochester, Vermont, 224p.

MAGURRAN A. E. (1998), Ecological Diversity and Its Measurement, Princeton University Press, Princeton, p. 7.

MEADOWS D. H, MEADOWS D. L, RANDERS D. L., RANDERS J., BEHRENS W. W. III (1972), The limits to growth: A report for the club of Rome's project on the predicament of mankind, Potomac Associates Books, Earth Island, London.

MUSILA W., TODT H., USTER D., DALITZ H. (2005), Is Geodiversity Correlated to Biodiversity? A Case Study of the Relationship Between Spatial Heterogeneity of Soil Resources and Tree Diversity in a Western Kenyan Rainforest, in: Huber B. A., Sinclair B. J., Lampe K.-H., African Biodiversity, Springer-Verlag, New York, p. 405-414.

NEGREI C. C. (1999), Environmental accounting [in Romanian], in: Vădineanu A., Sustainable development. Vol. 2. Mechanisms and instruments [in Romanian], Bucharest University Press, p. 136-158.

NORDIC CENTRE FOR SPATIAL DEVELOPMENT (2003), ESPON 1.1.1. Third interim report. The role, specific situation and potentials of urban areas as nodes in a polycentric development, NORDREGIO, p. 3.

NORDIC CENTRE FOR SPATIAL DEVELOPMENT (2005), ESPON 1.1.1. Potentials for polycentric development. Final Report, NORDREGIO, Sweden, p. 3.

PETRIŞOR A.-I. (2008), Urban ecology, sustainable spatial development and legislation [in Romanian], Editura Fundației România de mâine, Bucharest.

PETRIŞOR A.-I. (2009), Theory and practice of conserving biodiversity through urban and spatial plans [in Romanian], Amenajarea Teritoriului and Urbanismul 8(3-4), p.15-24. Press, $230 \mathrm{p}$. POPA M. E. (2007), Elements of geology and paleontology, Bucharest University SANTUCCI V. L. (2005), Historical Perspectives on Biodiversity and Geodiversity, Geodiversity \& Geoconservation 22(3), p.29-34.

SÂRBU C. N. (1999), Urban rehabilitation and development - a principal dimension of socio-economic transition. An example of approach: the urban texture, in: Vădineanu A., Sustainable development. Vol. 2. Mechanisms and instruments [in Romanian], Bucharest University Press, p. 298-329.

SÂRBU C. N. (2006), Housing in Romania: o framework approach [in Romanian], "Ion Mincu" University Press, Bucharest, p. 9-10.

TANSLEY A. G. (1935), The use and abuse of vegetational concepts and terms, Ecology,16, p. 284-307.

VĂDINEANU A. (1998), Sustainable development. Vol. I. Theoretical foundation of 
sustainable development [in Romanian], Bucharest University Press, Bucharest.

VĂDINEANU A. (2004), Management of development: a ecosystemic approach [in Romanian], Ars Docendi Press, Bucharest.

WILSON A. G. (2000), Complex Spatial Systems: The Modeling Foundations of Urban and Regional Analysis, Pearson Education, Harlow, UK, p. 6.

Received at : 15.04 .2010

Revised at: 16.05.2010

Accepted for publication at: 31.05.2010 